\title{
De las Pasiones en la Filosofía Medieval. A propósito de un libro reciente
}

\author{
Rodrigo Polanco \\ PONTIFICIA UNIVERSIDAD CATÓLICA DE CHILE \\ FACULTAD DE TEOLOGÍA
}

Acaban de ser publicadas por la profesora Gianina Burlando las Actas del X Congreso Latinoamericano de Filosofía Medieval, llevado a cabo en la Facultad de Filosofía de la Pontificia Universidad Católica de Chile, bajo el título De las Pasiones en la Filosofía Medieval (Lom, Santiago de Chile 2009).

El texto, con excelente presentación, está dedicado -como dice en el prólogo la editora- "al amplio campo de las pasiones humanas en el discurso filosófico especulativo del medioevo" (11). Este es un tema que interesa a la teología porque es importante volver siempre sobre los logros especulativos de la teología y filosofía medieval -en cuanto momentos de síntesis que se abren al futuro-, pero también, porque a la teología le interesa el tema de las pasiones como camino -según palabras de la misma editora- para "conocer la compleja experiencia humana" (11) desee un punto de unidad-como son las pasiones-, lo cual es indispensable para comprender en su globalidad el fenómeno humano.

El mundo cristiano -y particularmente el pensamiento medieval- no ha intentado aniquilar las pasiones -como sí lo hicieron otras escuelas de pensamiento-; muy por el contrario, quiere moderarlas, en el sentido de orientarlas y darles una estructura teológica. Esto es, se les asigna un lugar destacado en la tarea de conducir al hombre en la posesión del bien supremo: Dios. Se reconoce en esto a Santo Tomás (cf. 13-14). Y si se les asigna tan suprema tarea es porque, al mismo tiempo, se les reconoce un valor antropológico semejante. El tema de las pasiones, por eso mismo, explícita o implícitamente, supone una antropología unitaria desde la corporeidad. Aquí radica toda su actualidad, y al mismo tiempo, su auténtico componente católico. De ahí la importancia también de la presente publicación.

Si volvemos la mirada al pasado, comprobamos que los albores de la teología los podemos situar en la mitad del siglo II. Y se dieron en torno a un tema crucial: la salvación del hombre. Ello implicaba la pregunta acerca de qué es lo que se salva. Y por lo tanto, si se debe salvar todo el hombre, la pregunta se transformaba en qué es el hombre. Y siendo el hombre - desde una cosmovisión griega- 
un microcosmos, la pregunta terminaba siendo por la realidad y la bondad de la creación, lo cual recaía finalmente en Dios, responsable final del destino humano: el tema de Dios era el tema del hombre y viceversa. La temática nació desde la controversia con el gnosticismo, que planteaba, en buena medida, la identidad de naturaleza entre Dios y el hombre, al ser el "hombre verdadero", el destinado a subsistir, la así denominada "semilla espiritual" proveniente de la caída de la Sabiduría de lo Alto. Para el gnosticismo, como es sabido, homo=spiritus, lo que trae como consecuencia la desvalorización del componente material-corpóreo del hombre.

La Gran Iglesia percibió de inmediato las consecuencias teológicas de un planteamiento semejante, y fue Ireneo de Lyon, hacia el 170, quien elaboró una respuesta de tal manera adecuada, que no solo puso al descubierto la falacia que se escondía detrás del mito gnóstico, sino, sobre todo, dejó instaurada para siempre en el pensamiento cristiano la íntima relación carne-Espíritu, y por lo tanto, la unidad del hombre desde la carne. Su planteamiento es diáfano: no es necesario acabar con algo del hombre para que el hombre pueda unirse a Dios.

Basado en 1Tes 5,23 (“...que todo vuestro ser, el espíritu, el alma y el cuerpo, se conserve sin mancha"), afirma: "Tres son los elementos de los cuales consta el hombre perfecto: carne, alma y Espíritu. El Espíritu es el que configura y salva; la carne es unida y configurada; y el alma, que media entre los dos, cuando sigue al Espíritu es elevada por él, y cuando accede a la carne, sucumbe a las concupiscencias terrenas... [Quienes creen] tienen el Espíritu del Padre que purifica al hombre y lo eleva a la vida de Dios... Y el hombre viviente (homo vivens) está hecho de ambas cosas: viviente por participar del Espíritu, y hombre por la sustancia de la carne. Por lo tanto, la carne sin el Espíritu de Dios está muerta, y no teniendo vida, no puede poseer el Reino de Dios... En cambio, donde está el Espíritu del Padre, ahí se encuentra el hombre viviente (bomo vivens)... y la carne poseída por el Espíritu, olvidada de sí misma, asume la cualidad del Espíritu (qualitatem Spiritus), hecha conforme al Verbo de Dios (conformis facta Verbo Deı)" (AH V,9,1-3).

La antropología es clara: el hombre perfecto, pleno, ideado por Dios es carne + Espíritu. Por lo tanto, poseer el Espíritu de Dios no destruye al hombre sino que lo fortalece. El hombre recibe el Espíritu del Padre o Espíritu Santo y con eso puede participar de la sustancia del Padre, haciendo y teniendo como propio el componente divino. "Ireneo llama espirituales a los hombres por su participación cualitativa 'secundum carnem' en el Espíritu. Lo que en Dios es sustancia, en el hombre es cualidad ("qualitas spiritus)" (A. Orbe, Teología de San Ireneo. Comentario al Libro V del "Adversus haereses", I (Madrid 1985), 420. Cf. Ibíd. 417-437). El Espíritu hace a la carne inmortal e incorruptible, sin acabar con la carne misma. El hombre pasa a ser así testimonio viviente del poder de Dios que transforma (=salva) sin destruir. 
Pero la comunicación del Espíritu no es algo ni automático, ni estático, sino que supone la sumisión a sus mociones (conformis facta Verbo Dei). El ejemplo del olivo injertado expresa simbólicamente esta idea: "Así como el olivo silvestre cuando es injertado no pierde ciertamente la sustancia de madera, sino que cambia la cualidad del fruto y recibe otra denominación, y ya no se le llama olivo silvestre sino olivo fecundo; así también el hombre, por la fe injertado y al recibir el Espíritu de Dios, por cierto no pierde la sustancia de la carne, sino que cambia la cualidad del fruto de sus obras (substantiam carnis non amittit, qualitatem... immutat) y recibe otra denominación, para significar aquella transformación en algo mejor: ya no es carne y sangre sino que es y se llama un hombre espiritual (bomo spiritalis)" (AH V,10,2).

La respuesta de Ireneo a la pregunta por la unión Dios-carne se fundamenta en la distinción substantia-qualitas: Una sustancia puede recibir las cualidades de otra mejor, sin dejar de ser la sustancia que siempre ha sido. Así la carne y el Espíritu llegan a ser en el hombre la sustancia y su cualidad, y no una sustancia cambiada en otra sustancia (cf. A. Orbe, Teología..., 435-437; 482-483). Con todo esto, el Obispo de Lyon denuncia el error gnóstico, en donde la sustancia del hombre es precisamente el espíritu, devaluando así la carne y haciendo del hombre un ser divino 'por naturaleza' y no 'por gracia'. Para el Lugdunense, en cambio, el hombre llega a ser divino, pero por obra de la gracia misericordiosa de Dios, que dota de las cualidades divinas a la carne creada, al acoger sus mociones. ¿Puede uno entonces no ponderar en todo su valor antropológico las pasiones - entendidas como emociones, incluso afecciones-, a la hora del desarrollo del hombre con vistas a su fin último?

El tema devino clásico, aunque no siempre explícitamente tratado, ni con la hondura de Ireneo. Lo reencontramos - a modo de ejemplo- en san Ignacio de Loyola y su posteridad en el discernimiento de espíritus. Leemos en sus Reglas para en alguna manera sentir y conocer las varias mociones que en la ánima se causan: las buenas para recibir y las malas para lanzar: "Propio es de Dios y de sus ángeles, en sus mociones, dar verdadera alegría y gozo espiritual, quitando toda tristeza y turbación que el enemigo induce. Del cual es propio militar contra la tal alegría y consolación espiritual, trayendo razones aparentes, sutilezas y asiduas falacias" (Primera regla para la segunda semana); "En los que proceden de bien en mejor, el buen ángel toca a la tal ánima dulce, leve y suavemente, como gota de agua que entra en una esponja; y el malo toca agudamente y con sonido e inquietud, como cuando la gota de agua cae sobre la piedra. Y a los que proceden de mal en peor tocan los sobredichos espíritus contrario modo" (Séptima regla para la segunda semana) (Ejercicios Espirituales, Edición preparada por S. Arzubialde, Ediciones Mensajero, Bilbao $\left.{ }^{3} 2000,100-101\right)$. Con otro lenguaje y otras preocupaciones, encontramos aquí los mismos temas que nos ocupan: las mociones como elementos esencialmente humanos, nacidos ciertamente de la corporeidad 
del hombre, pero haciendo de gozne entre el Espíritu de Dios, que mueve y santifica y, el hombre, que se deja llevar por Dios. En palabras de san Ireneo: "En esto difiere Dios del hombre: Dios hace, en cambio el hombre es hecho (Deus quidem facit, homo autem fit)... aquel que es hecho debe recibir comienzo, adelanto y aumento hasta llegar a la madurez. Dios hace bien, y consecuentemente, el hombre es bien hecho... el hombre debe ir aprovechando y creciendo hacia Dios" (AH IV,11,2). La reflexión sobre las pasiones es un muy adecuado camino para comprender más profundamente que la gracia es don de Dios, pero que se regala al hombre y, se hace moción bumana donada.

Volviendo a la antigüedad cristiana -ahora en el siglo III- nos encontramos con otro gran autor, Orígenes, y con otro ángulo del mismo tema. En su reflexión teológica se encontró con abundantes textos bíblicos que hablaban de las pasiones en Dios Padre (A.T. passim). ¿Eran solo antropomorfismos y antropopatismos? El tema hacía problemas a la larga tradición filosófica de la "impasibilidad" de Dios, de la cual era heredero el Alejandrino. S. Fernández ha estudiado el tema y lo expone en un muy buen artículo: "Passio caritatis" According to Origen in Ezechielem Homiliae VI in the Light of Dt 1,31: Vigiliae Christianae 60, 135-147. Allí afirma que Orígenes, en una Homilía sobre Ezequiel 16,5 (LXX: "Ni mi ojo tuvo compasión de ti como para realizar en ti uno de todos estos beneficios, como para padecer algo por ti"), en donde se presenta el padecer como algo positivo en Dios, lo que aparentemente contradice la tradición filosófica y cristiana que afirma la impasibilidad como una característica divina, recurre a un ejemplo. Dice: "Voy a tomar un ejemplo de los hombres [...] Cuando le hablo a un hombre y le ruego por algo, para que se compadezca de mí, si no tiene misericordia, no padece nada por lo dicho por mí; si en cambio es de ánimo sensible y en él nada lo endurece con un corazón rígido, me escucha y tiene misericordia de mí, y se enternecen sus entrañas ante mis ruegos. Quiero que comprendas algo semejante sobre el Salvador: Bajó a la tierra porque tuvo misericordia del género humano [...] También el mismo Padre, el Dios del universo, que es longánime, lleno de misericordia y compasivo (Sal 102,8), ¿acaso no padece en cierto modo? ¿Acaso ignoras que, cuando administra las realidades humanas, padece una pasión humana? En efecto, el Señor, tu Dios, tomó tus maneras tal como un hombre tomaría a su hijo (Dt 1,31). Pues, Dios toma nuestras maneras tal como el Hijo de Dios lleva sobre sí nuestras pasiones. El propio Padre no es impasible. Si se le ruega, se compadece y se duele, padece por una cierta caridad, y, llega a estar en las [condiciones] en las que no puede estar de acuerdo con la magnitud de su naturaleza, y, por nosotros, soporta las pasiones humanas" (In E₹: hom., VI,6) (Ibíd., 139s).

Es claro que para Orígenes "Dios no es como un hombre que se enoja, y en ese sentido es impasible; pero no puede aceptar que Dios sea como un hombre que carece de misericordia, siendo en este otro sentido pasible". "Al centro del problema de la pasión divina está, ciertamente, el tema del lenguaje sobre Dios"; pero el Alejan- 
drino "va más allá, y afirmará que ese «lenguaje acomodado» tiene su fundamento en el ser de Dios. Hay una realidad que provoca y fundamenta la economía; en

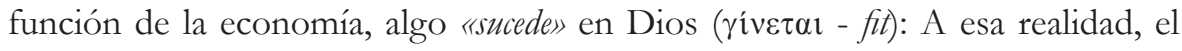
Alejandrino la llama pasión". Es el amor de Dios lo que permite comprender que Dios, en cierta medida, llega a ser lo que es incompatible con la magnitud de su naturaleza. "Dios no es pasible, porque no es como un hombre que se enoja; pero tampoco es impasible, porque no es como un hombre que no se inmuta" (Ibíd., 147). El lenguaje -según Orígenes-, aunque limitadamente, dice verdad sobre Dios. La imagen remite a la verdad. Hablar entonces de 'pasión' en Dios tiene sentido y verdad. A su vez hablar de pasión en el hombre tiene sentido teológico y remite a algo humano, pero que habla también de su semejanza con Dios y, por lo tanto, de algo que no acaba con la muerte. La pasión remite al "amor que no pasará" (1Cor 13,8), habla de la relación, de la donación, habla de Dios. En lenguaje Ireneano: la pasión es parte de la carne que está llamada a contemplar a Dios, porque la visión de Dios es la vida del hombre (AH IV,20,7). Y Dios no destruye lo humano, porque ha sido plasmado con sus manos, el Hijo y el Espíritu, y ha dejado sus huellas en su carne, ha dejado su capacidad de amar, de relacionarse (AH IV,20,1.4).

Estamos aquí a las puertas de lo que nuestro Santo Padre Benedicto XVI tan hermosamente nos ha dicho en su encíclica programática Deus caritas est. Dios es amor, esto es, agapé que ha integrado en sí también el eros, en una síntesis superior. Y esa caridad (agapé + eros) "es el don más grande que Dios ha dado a los hombres, es su promesa y nuestra esperanza" (Caritas in veritate 2). Por eso "el auténtico desarrollo del hombre concierne de manera unitaria a la totalidad de la persona en todas sus dimensiones" (Caritas in veritate 11), en donde necesita a Dios, para reconocer en el prójimo no solamente el otro, sino una auténtica imagen divina, "llegando así a descubrir verdaderamente al otro y a madurar un amor que 'es ocuparse del otro y preocuparse por el otro' (Deus caritas est 6)" (Caritas in veritate 11). Todo esto nos indica que el centro del desarrollo es la caridad. Pero eso depende de que los pueblos "se reconozcan como parte de una sola familia, que colabora con verdadera comunión y está integrada por seres que no viven simplemente uno junto al otro [...] Dicho pensamiento obliga a una profundización crítica y valorativa de la categoría de la relación... la criatura humana, en cuanto de naturaleza espiritual se realiza en las relaciones interpersonales" (Caritas in veritate 53). La reflexión de la pasiones en el hombre cobra así nueva actualidad y urgencia. 